\title{
Evaluation of antimicrobial, antioxidant and cytotoxic activities and characterization of bioactive substances from freshwater blue-green algae
}

\author{
Seddek N.H. ${ }^{1,{ }^{*}}$, Fawzy M.A. ${ }^{1,2}$, El-Said W.A. ${ }^{3}$ and Ahmed M.M.R. ${ }^{4}$ \\ ${ }^{1}$ Botany \& Microbiology Department, Science Faculty, Assiut University, Assiut, Egypt \\ ${ }^{2}$ Biology Department, Faculty of Science, Taif University, Taif, KSA \\ ${ }^{3}$ Chemistry Department, Faculty of Science, Assiut University, Assiut, Egypt \\ ${ }^{4}$ Botany \& Microbiology Department, Faculty of Science, New Valley University, New Valley, Egypt \\ Received: 12/11/2018, Accepted: 22/01/2019, Available online: 23/01/2019 \\ *to whom all correspondence should be addressed: e-mail: Nermienhelmyseddek@gmail.com, nhsali@iau.edu.sa \\ https://doi.org/10.30955/gnj.002949
}

\begin{abstract}
Organic solvent extracts of three cyanobacterial species (Anabaena oryzae, Oscillatoria sp. and Stigonema ocellatum) were tested for antimicrobial activity against human pathogenic fungal and bacterial strains as well as for antioxidant and cytotoxic activity against human breast adenocarcinoma (MCF-7). The acetone extract of Anabaena oryzae was found to be the most active one against tested fungal and bacterial strains. It showed a maximum antimicrobial activity against Serratia marcescens and Candida albicans. The methanol extract of Oscillatoria sp. exhibited the best total antioxidant capacity compared to the other solvents and algal species. Acetone and methanol extracts of Anabaena oryzae exhibited high toxicity against MCF-7 cell line with $\mathrm{IC}_{50}$ of 45.1 and $44.4 \mu \mathrm{g} / \mathrm{L}$, respectively. Acetone was the best solvent for extracting the active material. The acetone extracts were characterized by Gas Chromatography Mass Spectrophotometer (GC-MS) to identify the compounds responsible for such activities. Pharmaceutical important compounds in the acetone extract of cyanobacterial species like diacetone alcohol, acetic acid butyl ester mesityl oxide and heptadecane were present as a major component. These results indicate that extracts of studied cyanobacterial species exhibited appreciable antimicrobial, antioxidant and cytotoxic activity and could be a source of valuable bioactive materials for health products.
\end{abstract}

Keywords: Cyanobacteria, antimicrobial activity, antioxidant, anticancer, GC-MS.

\section{Introduction}

The organisms such as plants and animals as well as microorganisms (bacteria, algae, fungi) are well-known sources of compounds provided with interesting biological and therapeutic properties (Proksch et al., 2003). For example, more than $75 \%$ of drugs utilized to treat infectious diseases are derived from natural sources (Newman et al., 2003; El Gendy et al., 2016; Nermien et al., 2019). From this point of view, algae and cyanobacteria have been demonstrated to produce secondary metabolites other than those produced by terrestrial organisms (Faulkner, 1994). Microalgae and Cyanobacteria with reference to their microbial activity and in pharmaceutical aspects have been studied by various workers (Shaieb et al., 2014; Nermien and Fawzy, 2014; Abo-State et al., 2015). Cyanobacteria are morphologically, physiologically, and metabolically very diverse group, which makes them as a promising group of organisms for research on drugs discovery (Abed et al., 2011; Rama-Murthy et al., 2012). Although cyanobacteria are still primarily viewed as an environmental nuisance or a source of toxins, hazardous to man and aquatic livestock, there are many potential benefits to research on chemicals produced by these organisms. Antibacterial, antiviral, antifungal, algicide and cytotoxic activities have been reported (Schaeffer and Krylov, 2000; Suikkanen et al., 2004). The role of bioactive molecules in the producer organism itself is poorly understood, but, considering the wide spectrum of biological adaptations and tolerance to environmental stress revealed by cyanobacteria, some of these compounds can be produced in an attempt to confer advantages for their survival. Several studies showed that the bioactive compounds derived from cyanobacteria had an anticancer effect (Russo and Cesario, 2012). In Egypt, local cyanobacterial strains have proved to be a prolific source of antimicrobial agents (EI Semary, 2012; El Semarya and Mabrouk, 2013). Cyanobacteria are one of the most promising groups of organisms for the isolation of novel and biochemically active natural products (Burja et al., 2001). The cyanobacteria such as Nostoc commune (Jaki et al., 2000), Anabaena variabilis (Ma and Led, 2000), Nostoc spongiaeforme (Hirata et al., 1996), Microcystis aeruginosa, Anabaena flos-aquae (Khairy and El-Kassas, 
2010), Trichodesmium erythraeum (Thillairajasekar et al., 2004), Nodularia harveyana (Pushparaj et al., 1999) and Calothrix brevissima (Metting and Pyne, 1986) have been popularly reported to produce antimicrobial substances. Antimicrobial compounds have been previously detected in cyanobacterial extracts, such as Heptadecane and tetradecane from Spirulina platensis (Ozdemir et al., 2004), phenolic compounds from Nostoc muscorum (ElSheekh et al., 2006), peptides, polypeptides, amides and alkaloids from Fischerella ambigua (Ghasemi et al., 2004), lipopeptides from Anabaena spp. (Burja et al., 2001), fatty acids, tetramine, spermine and piperazine derivative from Anabaena spp. (Shanab, 2007), laxaphycins from Anabaena laxa (Frankmolle et al., 1992) and scytophytin from Scytonema psuedohofmanni (Ishibashi et al., 1986), these compounds have been reported to possess antimicrobial activity. Most of these compounds are synthesized by ribosomal pathways or by nonribosomal pathways. Invasive fungal infections caused by Candida spp. and Aspergillus spp. are common, especially in immunocompromised patients. The increase of antifungal resistance indicates an urgent need for new antifungal compounds (Khan et al., 2010). Cyanobacteria believed to be rich in antioxidants and phycobiliproteins (Mata et al., 2010) (PBPs) which are the unique photosynthetic pigments of cyanobacteria. These pigments have been widely used as natural colorants in foods, cosmetics, and pharmaceuticals, particularly as substitutes for synthetic dyes (Singh et al., 2005). Antioxidants play an important role in inhibiting and scavenging radicals, thus providing protection to humans against infections and degenerative diseases. The two most commonly used synthetic antioxidants; butylated hydroxyl anisole (BHA) and butylated hydroxyl toluene (BHT) are restricted because of their toxicity and DNA damage induction. Therefore, natural antioxidants from plant and algal extracts have attracted much attention because of safety. Algae generally have higher antioxidant activity due to higher contents of non-enzymatic antioxidant components, including ascorbic acid, reduced glutathione, phenols, and flavonoids (Wu et al., 2010). This study was conducted to elucidate the cytotoxicity, antimicrobial and antioxidants properties of three species of cyanobacteria namely Anabaena oryzae, Oscillatoria sp. and Stigonema ocellatum for future applications in medicinal and pharmaceutical industries, along with identifying their chemical profiles using GC/MS.

\section{Material and methods}

\subsection{Algae and culture conditions}

Three isolates were used in this study. Anabaena oryzae was isolated from the soil of El-Kharga Oasis (New Valley) in Egypt, while Oscillatoria sp. and Stigonema ocellatum were isolated from cultivated soil of agriculture faculty farm at Assiut University (Egypt) and identified according to Prescott (1978). The cultures were grown in BG11 medium (Rippka and Herdman, 1993) for screening the biological activities. Cultures were maintained at $28 \pm 2^{\circ} \mathrm{C}$ under continuous light intensity of $48 \mu \mathrm{mol} \cdot \mathrm{m}^{-2} \mathrm{~s}^{-1}$.

\subsection{Preparation of cyanobacterial extracts}

At the end of log phase, algal cultures were centrifuged and the pellets were collected, weighted and used for extraction of antimicrobial agents. $0.3 \mathrm{~g}$ of each algal pellet was extracted separately in acetone, ethyl acetate and methanol in a mortar pestle and kept overnight at $4{ }^{\circ} \mathrm{C}$ for complete extraction. The supernatant was collected after the centrifugation at $10000 \times \mathrm{xg}$ at $10 \mathrm{~min}$. The solvent extracts were concentrated under reduced pressure at $40^{\circ} \mathrm{C}$. Dry residue was redissolved in the different solvents to obtain final concentrations of $5 \mathrm{mg} / \mathrm{ml}$, then the extract kept at $4^{\circ} \mathrm{C}$ until use for bioassay.

\subsection{The growth of microorganisms set as microbial indicators}

\subsubsection{Bacterial strains and growth conditions}

The Anti-bacterial spectrum of the different extracts of three blue-green algae were tested against seven isolates of bacteria as following: three isolates of Gram-positive bacteria namely: Bacillus subtilis (Ehrenberg) Cohn, Micrococcus luteus (Schroeter) Chon and Staphylococcus aureus (Rosenbach), in addition to four isolates of Gramnegative bacteria namely: Escherichia coli (Migula) Castellani \& Chalmers, Klebsiella pneumoniae (Schroeter) Trevisan, Pseudomonas aeruginosa (Schroeter) Migula, and Serratia marcescens Bizio. Bacterial cultures were sub grown on fresh nutrient agar (NA) slants and incubated at $37^{\circ} \mathrm{C}$ for $24 \mathrm{~h}$ before used. All bacterial isolates were kindly obtained from the Clinical pathology Laboratories at Assuit University Hospital, Faculty of Medicine. Each bacterial biomass was prepared by inoculating $100 \mathrm{ml}$ of nutrient broth medium. Bacterial cultures were shaken $(250 \mathrm{rpm})$ at $32 \pm 2^{\circ} \mathrm{C}$ for $24 \mathrm{~h}$, resulting in suspension adjusted the turbidity to yield from $1 \times 10^{5}$ to $5 \times 10^{5}$ cells $/ \mathrm{ml}$ (0.5 McFarland standard).

\subsubsection{Candida species and growth conditions}

Three isolates of pathogenic Candida species were kindly obtained from the Assiut Unit Mycological Center (AUMC). They were previously isolated from women complaining of vaginal candidiasis (Farhan, 2011). These isolates were Candida albicans (Robin) Berkhout, Candida glabrata (Anderson) S.A. Meyei \& Berkhout and Candida krusei (Castellani) Berkhout. Candida cultures were grown on fresh Sabouraud dextrose agar medium (SDA) and incubated at $32 \pm 2{ }^{\circ} \mathrm{C}$ for $24 \mathrm{~h}$ before used. Inoculums of Candida strains were prepared by picking three distinct colonies of approximately $1 \mathrm{~mm}$ from 24 hours old culture grown on SDA and incubated at $35 \pm 2^{\circ} \mathrm{C}$. Colonies were suspended in $2 \mathrm{ml}$ of sterile $0.85 \%$ saline solution. Vortex the resulting suspension adjusted the turbidity to yield $1 \times 10^{5}-5 \times 10^{5}$ cells $/ \mathrm{ml}(0.5 \mathrm{McF}$ arland standard).

\subsubsection{Filamentous fungi and growth conditions}

Two isolates of filamentous fungi namely; Scopulariopsis brevicaulis and Penicillium aurantiogresium were kindly obtained from the AUMC. A modified Czapek's agar medium was used for growing these isolates. Seven days old of pure isolates were prepared to be as an indicator of the antifungal activities of all algal extracts. An inoculum of previous two filamentous isolates was prepared by 
taking the fungal growth of approximately $1 \mathrm{~cm}^{2}$ and suspended in $5 \mathrm{ml}$ distilled water supplemented with two drops of Tween 80 followed by vigorous shaking to get the spore suspension.

\subsection{Testing antimicrobial activity by the disc diffusion method}

Disc diffusion method (Sleigh and Timburg, 1981) is the powerful and widespread method used to measure Antimicrobial activities. A cell suspension of each test organism $10^{5}$ colony-forming units (CFU)/ml for bacteria or yeast cells were streaked on the surface of NA or SAD medium using a sterile cotton swab. In the case of filamentous fungi, $1 \mathrm{ml}$ fungal spore suspension was transferred into sterile Petri dishes before the suitable agar medium was poured, swirled and allowed to solidify. Sterilized filter paper discs $(0.5 \mathrm{~cm}$ diameter) Wattman No.1 were saturated with approximately $100 \mu$ l of each tested extract were placed on the surface of the inoculated medium (3 discs per plate). All plates which inoculated with bacteria or Candida were incubated at $35 \pm 2^{\circ} \mathrm{C}$ for 24 hours while the others were incubated at $28 \pm 2{ }^{\circ} \mathrm{C}$ for five days.

The inhibited diameter (average inhibition zones in $\mathrm{mm}$ ) of each indicator organism was measured and recorded as the antimicrobial activity of the algal extract. These inhibition activities were assessed by the diameter of average inhibition zones in relation to those of positive and negative controls. Standard antibiotics like Chloramphenicol (Cidostein $250 \mathrm{~g}$ - CID company) and Ampicillin (Ampicid 250 gm - CID company) were coassayed as positive controls for antibacterial activities while Ketoconazole and Itraconazole discs (HiMedia Company, India) were co-assayed as positive controls for Anti-fungal and anti-Candida activities. Sterilized filter paper saturated with each solvent were used as a negative control for all microbial indicators. All results were recorded as mean values of three replicates \pm standard deviation.

\subsection{Estimation of total antioxidant capacity}

Total antioxidant capacity (TAC) was measured in the different algal extracts using suitable kits according to guidelines of (Koracevic et al., 2001). The main principle of the determination of antioxidative capacity is performed by the reaction of antioxidants in the sample with a definite amount of exogenously provided hydrogen peroxide $\left(\mathrm{H}_{2} \mathrm{O}_{2}\right)$. The antioxidants in the sample eliminate a certain amount of the provided hydrogen peroxide. The residual $\mathrm{H}_{2} \mathrm{O}_{2}$ determined colorimetrically by an enzymatic reaction.

\subsection{Cytotoxicity assay}

Cytotoxicity investigations of all algal extracts were carried out on Human breast adenocarcinoma (MCF-7) based on the colorimetric MTT assay method which was conducted essentially according to the manufacturer's protocol. MCF-7 cells at a concentration of $2 \times 10^{5}$ cell $/ \mathrm{ml}$ were plated and grown in 96-well plates containing DMEM medium supplemented with $10 \%$ fetal bovine serum (FBS), incubation occurred at $37^{\circ} \mathrm{C}$ under conditions of $5 \% \quad \mathrm{CO}_{2}$, and $95 \%$ air for 24 hour prior to the addition of tested extracts. All studied algal extracts were dissolved in different solvents and diluted in the respective medium containing $1 \%$ FBS. Then, cells were treated with different concentrations of the different studied extracts for the next 24 hours; cells were treated with the same amount of the used solvents as a control. MTT $(0.5 \mathrm{mg} / \mathrm{ml})$ was added to each well and incubated for 4 hours. The insoluble formazan was dissolved in $100 \mu \mathrm{L}$ of DMSO at room temperature for $20 \mathrm{~min}$. Cell viability was assessed by measuring the absorbance at $540 \mathrm{~nm}$ using a microplate reader. The results were analyzed by means of cell viability curves and expressed with average of three measurements of $\mathrm{IC}_{50}$ values \pm standard deviation in Table 3 and Figure 2 .

\subsection{Cell culture}

Human breast adenocarcinoma (MCF-7) cancer cell line was obtained from the Institute of Vaccine and Serum (Cairo, Egypt). The MCF-7 cell line was cultured in PRMI (Invitrogen, Carlsbad, USA) with 10\% heat-inactivated fetal bovine serum and $2 \%$ antibiotics (streptomycin + penicillin). All cell lines were maintained under standard cell culture conditions at $37^{\circ} \mathrm{C}$ in an atmosphere of $5 \%$ $\mathrm{CO}_{2}$. The medium was changed every two days.

2.8. Analysis of algal crude extracts using gas chromatography mass spectrometry (GC-MS)

Identification of the chemical constituents of acetone extracts of cyanobacterial species was analyzed by Gas Chromatography-Mass Spectrometer (GC-MS), Agilent Model 7890A-5975B [Column, DB 5 ms, Agilent form (30 $\mathrm{m} \times 250 \mu \mathrm{m} \times 0.25 \mu \mathrm{m})]$ in the Unit of Analytical Chemistry, Department of Chemistry, Faculty of Science, Assiut University. The column was initially maintained for $2 \mathrm{~min}$ at $40^{\circ} \mathrm{C}$, and then the temperature was increased to $50^{\circ} \mathrm{C}$ at a rate of $4^{\circ} \mathrm{C} / \mathrm{min}$ and held for $3 \mathrm{~min}$, then increased to $150^{\circ} \mathrm{C}$ at a rate of $10^{\circ} \mathrm{C} / \mathrm{min}$ and held for $3 \mathrm{~min}$, then increased to $220^{\circ} \mathrm{C}$ at a rate of $10^{\circ} \mathrm{C} / \mathrm{min}$ and held for $6 \mathrm{~min}$, finally increased to $280^{\circ} \mathrm{C}$ at a rate of $15^{\circ} \mathrm{C} / \mathrm{min}$ and held for $10 \mathrm{~min}$. Helium (purity $99.999 \%$ ) was used as the carrier gas with a flow rate of $0.5 \mathrm{ml} / \mathrm{min}$ for $10.9 \mathrm{~min}$, then $1 \mathrm{ml} / \mathrm{min}$ per $\min$ to $1 \mathrm{ml} / \mathrm{min}$ for $30 \mathrm{~min}$. Neither internal nor external chemical standards were used in this chromatographic analysis. Interpretation of the resultant mass spectra were made using a computerized library-searching program (Willey 9 and NIST library) for the identification of the chemical constituents of algal extract.

\section{Experimental results}

\subsection{In vitro antimicrobial activities of different studied} blue-green algae

Antimicrobial activity of acetone, ethyl acetate and methanol of different species of blue-green algae (Anabaena oryzae, Oscillatoria sp. and Stigonema ocellatum) against tested different bacterial and fungal species was shown in Table 1. The algal extracts showed a different degree of antimicrobial activity and the intensity of inhibitory action varied depending on the species of 
microorganism, algal species and the type of solvent. Concerning the anti-bacterial activities of the investigated different algal extracts, we found that the acetone Anabaena extract was the most active one. Its inhibition activity was ranged from $30 \pm 0.7$ against Serratia marcescens to $4.0 \pm 0.0$ against Bacillus subtilis, it succeeded on the inhibition of growth all bacterial indicators except Staphylococcus aureus as shown in Table 1. It followed by acetone extract of
Stigonema ocellatum, it prevents the growth of all positive and negative bacterial indicator except Staphylococcus aureus and E.coli. Out of seven types of bacterial indicators, only Serratia marcescens was completely inhibited by all tested algal extracts with an average inhibition zone range $(5.0 \pm 0.1$ to $30 \pm 0)$ while $E$. coli was fierce microbe where it was sensitive only to acetone Anabaena extract.

Table 1. Antibacterial and antifungal activities of the cyanobacterial extracts

\begin{tabular}{|c|c|c|c|c|c|c|c|c|c|}
\hline & \multicolumn{9}{|c|}{ Inhibition of growth expressed as diameter of inhibition zone ( $\mathrm{mm})$} \\
\hline & \multicolumn{3}{|c|}{ Anabaena oryzae } & \multicolumn{3}{|c|}{ Oscillatoria sp. } & \multicolumn{3}{|c|}{ Stigonema ocellatum } \\
\hline & Acetone & $\begin{array}{c}\text { Ethyl } \\
\text { acetate }\end{array}$ & Methanol & Acetone & $\begin{array}{c}\text { Ethyl } \\
\text { acetate }\end{array}$ & Methanol & Acetone & $\begin{array}{c}\text { Ethyl } \\
\text { acetate }\end{array}$ & Methano \\
\hline \multicolumn{10}{|l|}{$\begin{array}{c}\text { Gram +ve } \\
\text { bacteria }\end{array}$} \\
\hline Bacillus subtilis & $4.0 \pm 0.0$ & - & - & - & - & - & $6.0 \pm 0.1$ & - & - \\
\hline $\begin{array}{c}\text { Micrococcus } \\
\text { luteus }\end{array}$ & $4.0 \pm 0.1$ & - & - & - & - & $2.0 \pm 0.2$ & $27.0 \pm 0.2$ & $27.0 \pm 0.3$ & - \\
\hline $\begin{array}{c}\text { Staphylococcus } \\
\text { aureus }\end{array}$ & - & $4.0 \pm 0.1$ & $3.0 \pm 0.3$ & - & - & - & - & - & - \\
\hline \multicolumn{10}{|l|}{ Gram -ve bacteria } \\
\hline E. coli & $20 \pm 0.4$ & - & - & - & - & - & - & - & - \\
\hline $\begin{array}{c}\text { Klebsiella } \\
\text { pneumoniae }\end{array}$ & $11 \pm 0.3$ & - & - & - & - & - & $4.0 \pm 0.2$ & $4.0 \pm 0.1$ & $3.0 \pm 0.0$ \\
\hline $\begin{array}{c}\text { Pseudomonas } \\
\text { aeruginosa }\end{array}$ & $8.0 \pm 0.0$ & - & - & $10.0 \pm 0.1$ & - & - & $3.0 \pm 0.05$ & - & - \\
\hline $\begin{array}{c}\text { Serratia } \\
\text { marcescens }\end{array}$ & $30 \pm 0.7$ & $9.7 \pm 0.05$ & $10.0 \pm 0.17$ & $30.0 \pm 0.0$ & $6.0 \pm 0.1$ & $11.0 \pm 0.1$ & $19.0 \pm 0.1$ & $8.0 \pm 0.05$ & $5.0 \pm 0.1$ \\
\hline \multicolumn{10}{|l|}{ Candida species } \\
\hline Candida albicans & $30 \pm 0.0$ & $3.0 \pm 0.3$ & $13.0 \pm 0.2$ & $25.0 \pm 0.2$ & $6.0 \pm 0.1$ & $19.0 \pm 0.2$ & $6.0 \pm 0.1$ & $6.0 \pm 0.1$ & - \\
\hline Candida glabrata & $10 \pm 0.1$ & $3.5 \pm 0.2$ & $3.0 \pm 0.0$ & $4.0 \pm 0.1$ & - & $6.0 \pm 0.0$ & - & - & - \\
\hline Candida krusei & $25 \pm 0.2$ & $10.0 \pm 0.4$ & $13.0 \pm 0.15$ & $17.0 \pm 0.5$ & - & $11.0 \pm 0.1$ & $7.0 \pm 0.2$ & $3.0 \pm 0.3$ & - \\
\hline \multicolumn{10}{|l|}{ Filamentous } \\
\hline $\begin{array}{c}\text { Scopulariopsis } \\
\text { brevicaulis }\end{array}$ & $7.0 \pm 0.1$ & - & - & - & - & - & - & - & - \\
\hline $\begin{array}{c}\text { Penicillium } \\
\text { aurantiogresium }\end{array}$ & $5.0 \pm 0.0$ & - & - & - & - & - & - & - & - \\
\hline
\end{tabular}

Note: Mean+SD $(n=3),{ }^{-}-$: no activity

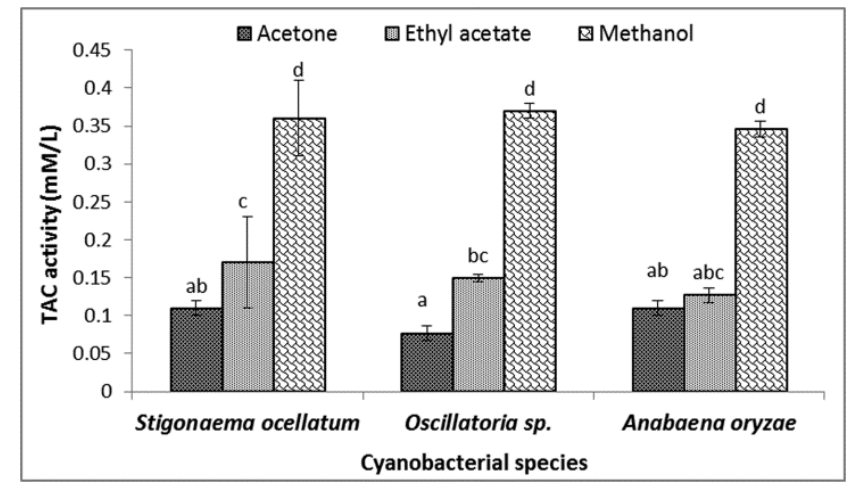

Figure 1. The total antioxidant capacity of different cyanobacterial extracts. The data are given as averages of three replicates \pm standard error. Values followed by the different letters within each column are significantly different at $\mathrm{p} \leq 0.05$.
The present findings on the antifungal activities of different algal extracts were represented as anti-Candida and anti-filamentous fungi. The results indicated that $C$. albicans was more sensitive than C. glabrata and C. krusei to all tested extracts. Candida species were inhibited by all tested algal extracts except methanol extract of Stigonema, their effect ranged between $3 \pm 0$ against $C$. albicans and $0.3 \pm 0$ against $C$. glabrata. When closely observed in Table 1 which showing the anti- Candida activities of studied algal extracts, all different extracts of Anabaena exhibited attractive anti-Candida properties. It worth to mention that, Acetone and methanol extracts of Oscillatoria demonstrated to be inhibitory against all different species of Candida. Whereas, their maximum inhibitory action was $25.0 \pm 0.2$ and $19.0 \pm 0.2$ against $C$. albicans while the minimum inhibitory action was $4.0 \pm 0.1$ and $6.0 \pm 0$ against $C$. glabrata, respectively. Concerning to anti-Candida activity of Stigonema, only acetone and ethyl 
acetate extracts achieved the desired aim against only $C$. albicans and $C$. krusei (Table 1). The antifungal activities of different algal extracts were also determined against Scopulariopsis brevicaulis and Penicillium aurantiogresium as filamentous fungal indicators. In general, algal extract showed similar antifungal activities, they had not any activity except acetone extract of Anabaena which was almost as active against the tested fungi. The antifungal inhibitory effect of this extract exhibited by $7.0 \pm 0.1$ and $5.0 \pm 0$ respectively against both filamentous fungal indicators (Table 1).

\subsection{Total antioxidant capacity (TAC):}

Data of the total antioxidant capacity in Figure 1 showed marked variation among both the different tested algal species and extracts. The methanol extract showed the best TAC activity for the three tested algae. In methanol extract, the best TAC Activity value was recorded in Oscillatoria sp. while the less value was obtained in Anabaena oryzae. In ethyl acetate extract, the arrangement of the three tested algae according to their total antioxidant capacity differed from the previous.
The higher TAC activity was at Stigonaema ocellatum and the less TAC was at Anabaena oryzae. On the other hand, acetone extract of Anabaena and Stigonaema gave the better TAC activity while Oscillatoria sp. gave the less total antioxidant capacity (Figure 1).

\subsection{Anticancer activities}

The cytotoxicity of the different extractions by using three different extraction solvents (acetone, methanol and ethyl acetate) were represented in Figure 2 . The data showed that for the three extracts that obtained from Anabaena oryzae by using acetone, ethyl acetate and methanol show high toxicity against MCF-7 cell line with $\mathrm{IC}_{50}$ of $45.1,58.7$ and $44.4 \mu \mathrm{g} / \mathrm{L}$, respectively. Also, three types of extracts from Oscillatoria showed toxicity activity with different $\mathrm{IC}_{50}$ of about $62.3,30.8$ and $130.7 \mu \mathrm{g} / \mathrm{L}$ for extracted that formed by using acetone, ethyl acetate and methanol, respectively. In addition, the acetone, ethyl acetate and methanol extract of Stigonema ocellatum have good cytotoxicity activities with $\mathrm{IC}_{50}$ values of about 49.1, 56.7 and $59 \mu \mathrm{g} / \mathrm{L}$, respectively (Figure 2).

Table 2. GC-MS analysis of the active components (in \% Relative Content) in acetone extract of blue green algal species

\begin{tabular}{|c|c|c|c|}
\hline Active compounds & A. oryzae & Oscillatoria sp. & S. ocellatum \\
\hline Mesityl oxide & 5.081 & 3.079 & 5.45 \\
\hline Diacetone alcohol & 89.247 & 59.562 & 89.26 \\
\hline 2,6-Dimethyl-6-nitro-2-hepten-4-one & 0.107 & - & 0.10 \\
\hline Heptadecane & 1.836 & 0.150 & 3.42 \\
\hline pentadecane & 0.872 & - & - \\
\hline Neophytadiene & 0.195 & 0.108 & - \\
\hline Phytol & 2.62 & 0.591 & 0.70 \\
\hline $\begin{array}{c}\text { 1,2-Benzenedicarboxylic acid, bis(2-ethylhexyl) } \\
\text { ester (CAS) }\end{array}$ & 0.042 & - & 0.41 \\
\hline Acetic acid, butyl ester & - & 31.041 & - \\
\hline m-Xylene & - & 0.306 & - \\
\hline 2,6,10,14-Tetramethyl heptadecane & - & 0.326 & - \\
\hline 2-Ethoxy-2-methylbutane & - & 0.228 & - \\
\hline Propanedioic acid, dimethyl ester & - & 0.143 & - \\
\hline $\begin{array}{l}\text { Hexaethylene glycol dimethyl ether; } \\
2,5,8,11,14,17,20 \text {-Heptaoxaheneicosane }\end{array}$ & - & 0.278 & - \\
\hline Propylene Glycol Trimer 3 & - & 0.278 & - \\
\hline Phthalic acid, mono-(2-ethylhexyl) ester & - & 1.037 & - \\
\hline 2,6,10-trimethyl,14-ethylene-14-pentadecne & 0.195 & - & 0.23 \\
\hline (3E)-3-Icosene & - & - & 0.11 \\
\hline (Z)-14-Tricosenyl formate & - & - & 0.07 \\
\hline 6-Octen-1-ol, 3,7-dimethyl-, acetate & - & - & 0.08 \\
\hline 9-Hexadecenoic acid octadecyl ester & - & - & 0.06 \\
\hline Hexadecanoic acid, methyl ester & - & 0.074 & 0.05 \\
\hline
\end{tabular}




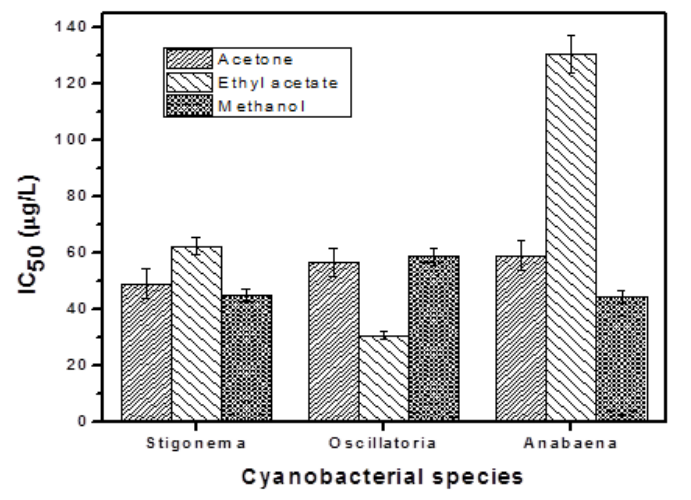

Figure 2. The values of $I C_{50}(\mu \mathrm{g} / \mathrm{L})$ of different cyanobacterial extracts against human breast adenocarcinoma (MCF-7)

Table 3. The values of the average $I C_{50}(\mu \mathrm{g} / \mathrm{L}) \pm$ standard deviation (SD) of different cyanobacterial extracts against human breast adenocarcinoma (MCF-7)

\begin{tabular}{|c|c|c|}
\hline $\begin{array}{c}\text { Algal } \\
\text { Species }\end{array}$ & solvent & $\mathrm{IC}_{50}(\mu \mathrm{g} / \mathrm{L}) \pm \mathrm{SD}$ \\
\hline \multirow[t]{3}{*}{ Stigonema } & Acetone & $49.1 \pm 1.25$ \\
\hline & Ethyl acetate & $56.7 \pm 1.45$ \\
\hline & Methanol & $59 \pm 1.51$ \\
\hline \multirow[t]{3}{*}{ Oscillatoria } & Acetone & $62.3 \pm 1.59$ \\
\hline & Ethyl acetate & $30.8 \pm 0.79$ \\
\hline & Methanol & $130.7 \pm 3.33$ \\
\hline \multirow[t]{3}{*}{ Anabaena } & Acetone & $45.1 \pm 1.15$ \\
\hline & Ethyl acetate & $58.7 \pm 1.497$ \\
\hline & Methanol & $44.4 \pm 1.13$ \\
\hline
\end{tabular}

3.4. GC-MS Analysis of active algal extracts

In this work, acetone extract of the target species was found to be most active when compared to the other extracts. So, this extract was further selected for its GCMS analysis. A total of 22 chemical compounds were found from the acetone extract of the cyanobacterial species. The chemical composition of the extract varied from alga to other with the highest number of compounds was found in Oscillatoria sp. (14 compounds) followed by Stigonema ocellatum (12 compounds) and Anabaena oryzae (9 compounds), however a few of them were predominant (Table 2). The results showed that the most bioactive compounds produced in major amounts by Oscillatoria sp. was diacetone alcohol, acetic acid butyl ester and mesityl oxide representing 59.56\%, 31.04\% and $3.08 \%$, respectively. The components of Anabaena oryzae also consisted of diacetone alcohol (89.25\%) and mesityl oxide $(5.08 \%)$ as major components. Similarly, diacetone alcohol (89.26\%), mesityl oxide (5.45\%) and heptadecane (3.42\%) were abundantly present in the acetone extract of Stigonema ocellatum. Other compounds such as 2,6Dimethyl-6-nitro-2-hepten-4-one, neophytadiene, phytol, 1,2-Benzenedicarboxylic acid bis(2-ethylhexyl) ester, 2,6,10-trimethyl,14-ethylene-14-pentadecne and hexadecanoic acid methyl ester, have been reported to be a common minor volatile component in some cyanobacterial species. A small amount of pentadecane was only detected in Anabaena oryzae (0.872\%). While, m-Xylene, 2,6,10,14-Tetramethylheptadecane, 2-Ethoxy2-methylbutane, propanedioic acid dimethyl ester, hexaethylene glycol dimethyl ether, propylene glycol trimer 3 and phthalic acid mono-(2-ethylhexyl) ester were detected only in small amounts by Oscillatoria sp. On the other hand, (3E)-3-Icosene, (Z)-14-Tricosenyl formate, 6Octen-1-ol 3,7-dimethyl- acetate and 9-Hexadecenoic acid octadecyl ester were estimated only in Stigonema ocellatum (Table 2).

\section{Discussion}

The present study is a strive towards the production of antibiotics, antifungals and antioxidants by the blue-green algae namely; Anabaena oryzae, Oscillatoria sp. and Stigonema ocellatum which screened for their antimicrobial activities against different species of pathogenic bacteria and fungi as well as antioxidant and anticancer activities. Finding an antimicrobial activity for tested algae in vitro experiments is predictive of their capacity to produce new compounds which act as antibacterial and antifungal compounds. It was found that Anabaena oryzae has high biological activity against all Gram positive and negative bacterial strains in addition to three species of Candida and species of filamentous fungi. Also, acetone extract of Anabaena was the most active one; similar results were described earlier by Rao (2015) who found that a acetone culture crude extract of Anabaena oryzae exhibited the antibacterial activity with a maximum zone of inhibition $15.50 \mathrm{~mm}$ against the strain of Salmonella typhi followed by $10.33 \mathrm{~mm}$ inhibition zone was found in methanol extract against Klebsiella aerogenes. Acetone extract of Stigonema ocellatum also exhibited an inhibitory action; it prevents the growth of all positive and negative bacteria indicators except Staphylococcus aureus and E. coli. In our knowledge, no literature about antimicrobial activities of Stigonema ocellatum extracts except Malathi et al. (2016). They screened antimicrobial activity of Anabaena circinalis, Nostoc muscorum, Stigonema ocellatum and Hapalosiphon welwitschii by using the Agar disc diffusion method against pathogenic bacteria and fungi and they found that chloroform and hexane extracts of $S$. ocellatum culture were expressed good antibacterial activity with $19.3 \pm 0.88 \mathrm{~mm}$ and $10.3 \pm 0.33 \mathrm{~mm}$ zone of inhibition against Klebsiella pneumoniae and $E$. coli, respectively. Also, they recorded the antifungal activity of $S$. ocellatum extract against Aspergillus fumigatus.

Total antioxidant capacity was found to be higher in the methanolic extract than in ethyl acetate extracts and the lowest values showed at acetone extracts of the three tested algae. Similarly, Sivakumar and Rajagopal (2011) reported that the highest antioxidant activity was observed in the methanol extract from eight green algal species. Uma et al. (2011) observed that the methanolic extracts displayed greater potential in all antioxidant assays when compared to ethanolic and acetone extract of green microalgae Desmococcus olivaceous and 
Chlorococcum humicola. Concerning to the methanol extract the highest antioxidant activity was recorded in the methanolic extract of Oscillatoria sp. $\quad(0.37 \pm 0.01$ $\mathrm{mM} / \mathrm{L}$ ). Methanolic extracts showed antioxidant activity in the order of Oscillatoria sp. > Stigonaema ocellatum > Anabaena oryzae. Methanol is a good multifunctional solvent for preliminary extraction (Harborne, 2006), so that it has been used for marine algal antioxidant extraction (Khumar et al., 2008). Methanol concentration for extraction influences the total phenol content (Chew et al., 2008) and the antioxidant activity of the marine algae (Damongilala et al., 2013). The antioxidant activity of the alga Anabaena oryzae was low, almost among the different tested extracts. This low antioxidant activity can be attributed to the low, and perhaps the lack of, antioxidant compounds with high antioxidant property such as phenol and flavonoid in the non-polar extracts of the algae (Muret et al., 2007). Phenolic compounds (in marine algae) are correlated with antioxidant activity and also dependent on the solvent and algal species used for extraction (Horincar et al., 2011).

Furthermore, the cytotoxicity of all extractions demonstrated that although all extractions show good cytotoxicity, however, their cytotoxicity activity was different based on the type of algae and the solvent of the extraction. The three types of extracts from Oscillatoria showed the highest cytotoxicity in comparing to the all different extractions from the three different bacteria types and the extract that was obtained by using ethyl acetate have the lowest $I C_{50}$ highest cytotoxicity activities. Also, the three extracts from Stigonema showed almost equal cytotoxicity activities that are near to the cytotoxicity activity of extraction from Oscillatoria by using methanol or acetone. In addition, the two extracted from Anabaena by using methanol or acetone have shown good cytotoxicity activities almost like that from Oscillatoria or from Stigonema, however the extract from Anabaena by using ethyl acetate showed the lowest cytotoxicity activity in comparing with all the other extracts. The result of the compound assay from the acetone extract of cyanobacterial species using GC-MS shows that there were several compounds contained in the extract. Based on the identification result using GC$\mathrm{MS}$, the compounds that were extracted belonged to benzene, aromatic hydrocarbon, ketones, alcohols and fatty acid groups. High amounts of diacetone alcohol were detected in all tested cyanobacterial species. Maligan et al. (2013) reported that Tetraselmis chuii extract using acetone solvent was also contained high amounts of diacetone alcohol (53.617) which is in good agreement with our results. Alcohol groups have a toxic effect on microorganism (Sikkema et al., 1995). Mesityl oxide is a ketone has been reported to be common in all studied cyanobacterial species. Hydrocarbons, alcohol, and ketones have inhibitory activity against mold, yeast, and bacteria. Whereas the antifungal activity of the alcohol groups was delayed the growth of fungal conidia (Helal et al., 2006). The majority of cyanobacterial species also contains small amounts of short-chain hydrocarbons (Murata and Nishida, 1987) like heptadecane. In this study, small amounts of heptadecane $(1.836 \%, 0.150 \%, 3.42 \%)$ were detected in Anabaena oryzae, Oscillatoria sp. and Stigonema ocellatum, respectively. Previous records reported that Spirulina platensis consisted of heptadecane (39.70\%) and tetradecane (34.61\%) which can inhibit some Gram +ve and Gram -ve bacteria and Candida albicans (Ozdemir et al., 2004). Khairy and El-Kassas (2010) stated that the most bioactive compound produced by Anabaena flos-aquae was heptadecane and 7methylheptadecane representing 26.11, 18.65\%, respectively. The phytols are an acyclic diterpene alcohol, also known as farnesol were present as lower contents in the tested cyanobacterial species. These compounds have proven antibacterial action against Staphylococcus aureus, MRSA (Methicillin Resistant S. aureus) \& MSSA (Methicillin Susceptble S. aureus) (JabraRizk et al., 2006) and fungal growth inhibition (Sato et al., 2004). Farnesol has the ability to sensitize $S$. aureus to antimicrobials when used in synergy with antimicrobials. Therefore, it has been suggested for a potential application as an adjuvant therapeutic agent against biofilm related infections involving MRSA and thereby counteracting drug resistance. Farnesol is also known to possess chemopreventive and anticancerous activity by unknown mechanisms. Small contents of 1,2Benzenedicarboxylic acid, bis(2-ethylhexyl) ester was present in the acetone extract of Anabaena oryzae and Stigonema ocellatum. This compound is known as phthalate derivative; it exhibit a pronounced antibacterial action whereas, it can react with a hydrophobic side of the cell membrane which causes disruption of the permeability of the cell membrane (Uyeda et al., 1990). Bharat et al. (2013) reported that, this compound has potent antibacterial activity and was present in Chrococcus sp. (0.56\%), Aulosira fertillisma (10.64\%), Anabaena variabilis (4.55\%) \& Westiellopsis prolifica (1.58\%) which also showed the higher zone of inhibitions (16.06, 30.04, $33.36 \& 25.93 \mathrm{~mm}$ ) and lower MIC of 64 to $128 \mu \mathrm{g} / \mathrm{ml}$ against $S$. aureus 25923. Fatty acids largely known in cyanobacteria are Octadecanoic, Octadecenoic, hexadecanoic acids, hexadecenoic acids, hexadecadienioc (Murata and Nishida, 1987). The fatty acids hexadecanoic acid methyl ester was present in the acetone extract of Oscillatoria sp. and Stigonema ocellatum as well as 9-hexadecenoic acid octadecyl ester was only estimated in Stigonema ocellatum extract affording antimicrobial and cytotoxic action. Several types of fatty acid compounds that have an antimicrobial activity such as linoleic acid, n-hexadecanoic acid, and 9 hexadecenoic acid (Agoramoorthy et al., 2007). 9-hexadecenoic acid has an effect on membrane permeability and ion partitioning on the cell membrane layer of microorganisms (Langner and Hui 2000). Antibacterial, antioxidant, and cytotoxic activity were due to the synergistic effect of all above compounds.

\section{Conclusions and future prospects}

Cyanobacteria are known to be the spearhead organisms in major habitats and along with their diversity in 
structure and ability to produce a wide range of compounds. Despite their omnipresence and a large body of obtainable information on cyanobacterial metabolites and their biological properties, there is a paucity of application-oriented research regarding their roles in drug development and production of new industrial compounds. Collective efforts are needed to scout the chemical, biological and genetic diversity of cyanobacteria for controlling Plant, human and animal diseases that hinder advances in agriculture, drug industry or proliferation of human life. Future research also needs to be lead to bioprospecting cyanobacterial diversity in symbiotic associations for novel chemicals. Also, efforts need to be taken to identify novel genes/molecules or drug discovery from isolates belonging to new habitats.

\section{References}

Abed R.M., Dobrestov S., Al-Kharusi S., Schramm A., Jupp B. and Golubic S. (2011), Cyanobacterial diversity and bioactivity of inland hypersaline microbial mats from a desert stream in the Sultanate of Oman, Fottea, 11, 215-224.

Abo-State M.A., Shanab S.M., Ali H.E. and Abdullah M.A. (2015), Screening of antimicrobial activity of selected Egyptian cyanobacterial species, Journal of Ecology of Health \& Environment, 3, 7-13.

Agoramoorthy G., Chandrasekaran M., Venkatesalu V. and Hsu M.J. (2007), Antibacterial and antifungal activities of fatty acid methyl esters of the blind-your-eye mangrove from India. Brazilian Journal of Microbiology, 38, 739-742.

Bharat N., Md I., Md M.R.A. and Fatma T. (2013), Antimicrobial and cytotoxic activities of cyanobacteria. International Journal of Innovative Research in Science, Engineering and Technology, 2, 4328-4343.

Burja A.M., Banaigs B., Abou-Mansour E., Burgess J.G., Wright P.C. (2001), Marine cyanobacteria - a prolific source of natural products. Tetrahedron, 57, 9347-9377.

Chew Y.L., Lim Y.Y., Omar M. and Khoo K.S. (2008), Antioxidant activity of three edible seaweeds from two areas in South East Asia, LWT-Food Science and Technology, 41, 1067-1072.

Damongilala L.J., Widjanarko S.B., Zubaidah E. and Runtuwene M.R.J. (2013), Antioxidant activity against methanol extraction of eucheuma cotonii and E. spinosum collected From North sulawesi waters, Indonesia, Food Science and Quality Management, 17, 7-13.

El Gendy S.G., Nermien H.S. and Mohammed S.M. (2016), Activity of some natural oils on dermatophytes isolated from assuit University hospitals, Egyptian Journal of Medical Microbiology, 25, 85-91.

El Semary N.A. (2012), The characterisation of bioactive compounds from an Egyptian Leptolyngbya sp. strain. Annals of Microbiology, 62, 55-59.

El Semary N.A. and Mabrouk M. (2013), Molecular characterization of two microalgal strains from Egypt with antimicrobial activity of their extracts, Biotechnology, Agronomy, Society and Environment, 17, 312-320.

El-Sheekh M.M., Osman M.E.H., Dyab M.A., Amer M.S. (2006), Production and characterization of antimicrobial active substance from the cyanobacterium Nostoc muscorum. Environmental Toxicology and Pharmacology, 21, 42-50.
Farhan M.A. (2011), Mycological Studies of Genital Tract in Women. M.Sc. Thesis. Botany Department, Faculty of Science, Assiut University, Egypt.

Faulkner D.J. (1994), Marine natural products, Natural Product Reports, 11, 355-394.

Frankmolle W.P., Larsen L.K., Caplan F.R., Patterson G.M.L., Knubel G., Levin I.A. and Moore R.E. (1992), Antifungal cyclic peptides from the terrestrial blue green algae Anabaena laxa. 1. Isolation andbiological properties, The Journal of Antibiotics, 45, 1451-1457.

Ghasemi Y., Tabatabaei Y., Shafiee A., Amini M., Shokravi S.H. and Zarrini G. (2004), Parsiguine, a novel antimicrobial substance from Fischerella ambigua, Pharmaceutical Biology, 2, 318-322. http://dx.doi. org/10.1080/13880200490511918

Harborne J.B. (1984), Phytochemical Methods. 2nd edition, Chapman and Hall Publications. London, New York, p. 288.

Helal G.A., Sarhan M.M., Abu Shahla A.N.K. and Abou El-Khair E.K. (2006), Antimicrobial activity of some essential oils against microorganisms deteriorating fruit juices, Mycobiology Journal, 34, 219-229.

Hirata K., Takashina J., Nakagami H., Ueyama S., Murakami K., Kanamori T. and Miyamoto K. (1996), Growth inhibition of various organisms by a violet pigment nostocine $A$, produced by Nostoc spongiaeforme, Bioscience, Biotechnology, and Biochemistry, 60, 1905-1906.

Horincar V., Parfene G. and Bahrim G. (2011), Evaluation of bioactive compounds in extracts obtained from three romanian marine algae species, Romanian Biotechnological Letters, 6, 71-78.

Ishibashi M., Moore R.E., Patterson G.M.L., Xu C. and Clardy J. (1986), Scytophycins, cytotoxic and antimycoticagents from cyanophyte Scytonema pseudohofmanii, The Journal of Organic Chemistry, 51, 5300-5306.

Jabra-Rizk M.A., Meiller T.F., James C.E. and Shirtliff M.E. (2006), Effect of farnesol on Staphylococcus aureus Biofilm formation and antimicrobial susceptibility, Antimicrobial Agents and Chemotherapy, 50, 1463-1469.

Jaki B., Orjala J., Heilmann J., Linden A., Vogler B. and Sticher O. (2000), Novel extracellular diterpenoids with biological activity from the cyanobacterium Nostoc commune, Journal of Natural Products, 63, 339-343.

Khairy H.M. and El-Kassas H.Y. (2010), Active substance from some blue green algal species used as antimicrobial agents, African Journal of Biotechnology, 9, 2789-2800.

Khan M.S.A., Ahmad I., Aqil F., Owais M., Shahid M. and Musarrat J. (2010), Virulence and pathogenicity of fungal pathogens with special reference to Candida albicans. In: Ahmad I., Owais M., Shahid M. and Aqil F. (Eds.), Combating Fungal Infections, Springer-Verlag, Berlin, Germany, pp. 2145.

Khumar S.K., Ganesan K. and Subba R.P.V. (2008), Antioxidant potential of solvent extract of Kappaphycus alvarezii doty Doty-an Edible Seaweed, Food Chemistry, 107, 289-295.

Koracevic D., Koracevic G., Djordjevic V., An drejevic S. and Cosic V. (2001), Method for the measurement of antioxidant activity in human fluids, Journal of Clinical Pathology, 54, 356-361.

Langner M. and Hui S. (2000), Effect of free fatty acids on the permeability of 1, 2-dimyristoyl-sn-glycero-3-phosphocholine bilayer at the main phase transition, BBA-Biomembranes, $1463,439-447$. 
Ma L. and Led J.J. (2000), Determination by high field NMR spectroscopy of the longitudinal electron relaxation rate in Cull plastocyanin from Anabaena variabilis, Journal of the American Chemical Society, 122, 7823-7824.

Malathi T., Ramesh M., Babu D., Srinivas B. and Digamber R. (2016), Evaluation of antimicrobial activity of the different culture extracts of cyanobacterial species, International Journal of Pharma and Bio Sciences, 7, 371-378.

Maligan J.M., Adhianata H. and Zubaidah E. (2013), Production and identification of antimicrobial compounds from marine microalgae Tetraselmis chuii using ultrasound assisted extraction method.

Mata T.M., Martins A.A. and Caetano N.S. (2010), Microalgae for biodiesel production and other applications:a review, Renewable and Sustainable Energy Reviews, 14, 217-232.

Metting B. and Pyne J.W. (1986), Biologically active compounds from microalgae enzyme, Microbial Technology, 8, 386-394.

Murata N. and Nishida I. (1987). The Biochemistry of Plants. In P.K. Stmf (ed).: Academic press, New York, 9, 315-347.

Muret K., Sevgi K. and Sengul K. et al. (2007), Biological activities, chemical composition of three honeys of different types from Anatolia. Food chemistry, 100, 526-534.

Nermien H.S. and Fawzy M.A. (2014), Antibacterial and antifungal activities of extract of cyanobacteria Anabaena oryzae and Spirulinaplatensis. Journal for Advanced Research in Applied Sciences, 1, 10-19.

Newman D.J., Cragg G.M. and Snader K.M. (2003), Natural products as sources of new drugs over the period 1981-2002, Journal of Natural Products, 66, 1022-1037.

Ozdemir G., Karabay N., Dolay M. and Pazarbasi B. (2004), Antibacterial activity of volatile extracts of Spirulina plantensis, Phytotherapy Research, 18, 754-757.

Prescott G.W. (1978), How to Know the Freshwater Algae, Brown Company Publishers. 272 pp.

Proksch P., Edrada-Ebel R.A. and Ebel R. (2003), Drugs from the sea-Opportunities and obstacles, Marine Drugs, 1, 5-17.

Pushparaj B., Pelosi E. and Juttner F. (1999), Toxicological analysis of the marine cyanobacterium Nodularia harveyana, Journal of Applied Phycology, 10, 527-530.

Rama-murthy V., Raveendran S., Thirumeni S. and Krishnaveni S. (2012), Antimicrobial activity of heterocytic cyanobacteria, International Journal of Advanced Life Sciences, 1, 32-39.

Rao B.D. (2015), Antibacterial activity of fresh water cyanobacteria. Journal of Algal Biomass Utilization, 6, 60- 64.

Rippka R. and Herdmann M. (1993), Pasteur culture collection of cyanobacterial strains in axenic culture, Institut Pasteur, and Paris, France. Catalogue of Strains 103.

Russo P. and Cesario A. (2012), New anticancer drugs from marine cyanobacteria, Current Drug Targets, 13, 1048-1053.

Sato T., Watanabe T., Mikami T. and Matusumoto T. (2004), Farnesol, a morphogenetic autoregualtory substance in the dimorphic fungus Candida albicans, inhibits hyphae growth through suppression of a mitogen-activated protein kinase cascade, Biological Pharmaceutical Bulletin, 27, 751-752.

Schaeffer D.J. and Krylov V.S. (2000), Anti-HIV activity of extracts and compounds from algae and cyanobacteria, Ecotoxicology and Environmental Safety, 45, 208-227.

Shaieb F.A., Issa A.A.S. and Meragaa A. (2014), Antimicrobial activity of crude extracts of cyanobacteria Nostoc commune and Spirulina platensis, Archives of Biomedical Sciences, 2, 34-41.
Shanab S.M.M. (2007), Bioactive allelochemical compounds from Oscillatoria species Egyptian Isolates, International Journal of Agriculture and Biology, 9, 617-621.

Sikkema J., De Bont J.A. and Poolman B. (1995), Mechanisms of membrane toxicity of hydrocarbons, Microbiological Reviews Journal, 59, 201-222.

Singh S., Kate B.N. and Banerjee U. (2005), Bioactive compounds from cyanobacteria and microalgae: an overview, Critical Reviews in Biotechnology, 25, 73-95.

Sivakumar K. and Rajagopal S.V. (2011), Radical scavenging activity of green algal species, Journal of Pharmacy Research, 4, 723-725.

Sleigh J.D. and Timburg M.C. (1981), Notes on Medical Bacteriology, Churchill Livingstone, London.

Suikkanen S., Fistarol G.O. and Granéli E. (2004), Allelopathic effects of the Baltic Cyanobacteria Nodularia spumigena, Aphanizomenon flos-aquae and Anabaena lemmermannii on algal monocultures. Journal of Experimental Marine Biology and Ecology, 308, 85-101.

Thillairajasekar K., Duraipandiyan V., Perumal P. and Ignacimuthu S. (2004), Antimicrobial activity of Trichodesmium erythraeum Ehr microalga from South East coast of Tamil Nadu, India, International Journal of Integrative Biology, 5, 167-170.

Uma R., Sivasubramanian V. and Niranjali Devaraj S. (2011), Evaluation of in vitro antioxidant activities and antiproliferative activity of green microalgae, Desmococcus olivaceous and Chlorococcum humicola, Journal of Algal Biomass Utilization, 2, 82-93.

Uyeda M., Suzuki K. and Shibata M. (1990), 3315-AF2, a cell aggregation factor produced by Streptomyces sp. strain no. A-3315, Agricultural and Biological Chemistry Journal, 54, 251-252.

Wu S.C., Wang F.J. and Pan C.L. (2010), The comparison of antioxidative properties of seaweed oligosaccharides fermented by two lactic acid bacteria, Journal of Marine Science and Technology, 18, 537-545 